\title{
Vegetative Propagation in Piperaceae Species
}

\author{
Luiz Antonio de Souza*, Ismar Sebastião Moscheta, Káthia Socorro Mathias Mourão, \\ Adriana Lenita Meyer Albiero, Maísa de Carvalho Iwazaki, Jonathas Henrique Georg de \\ Oliveira and Sônia Maciel da Rosa \\ Departamento de Biologia; Universidade Estadual de Maringá; Av. Colombo, 5790; 87020-900; Maringá - PR - \\ Brasil
}

\begin{abstract}
Piperaceae species of forest remnants of Maringá, Paraná, Brazil present vegetative propagation through root or stem (stolon). This reproduction type was verified in Piper amalago L., P. arboreum Aublet, P. xylosteoides (Kunth) Steud., Peperomia parnassifolia Miq. and Ottonia martiana Miq. Root and stem branches of these species were analyzed anatomically. Results indicated that the vegetative propagation in Piperaceae should be studied in other forests. New and additional studies should be made if the structural variations were induced environmentally or fixed genetically.
\end{abstract}

Key words: Piperaceae, vegetative reproduction, stolon, stem, root

\section{INTRODUCTION}

The Piperaceae, while not so large a family as a number of others are nonetheless is considered a comparatively big one, conservatively estimated to contain at least 2000 or probably more species. Members of the family occur throughout the tropics of both the hemispheres, with major concentrations and centers of dispersal occurring in Latin America and in Malaysia. In the United States, only a few species of Peperomia Ruiz and Pavon are found in southern Florida (Yuncker, 1958). Brazilian forests harbour 283 species of Piper L., 25 species of Ottonia Sprengel, 459 species of Peperomia, and two species of Pothomorphe Miquel (Yuncker, 1972, 1973, 1974, 1975).

The Piperaceae species are erect or scandent shrubs, small trees, or succulent, terrestrial or epiphytic herbs, with stems commonly more or less nodose (Yuncker, 1972; Judd et al., 2001).

The most familiar commercial product of the Piperaceae is pepper, a condiment made from the pulverized fruits of Piper nigrum L. Other species of Piper, such as P. betle L., P. methysticum G. Forst., and $P$. cubeba L. F., are the source of other well known spices or masticatories. Some species of Piper have diverse local medicinal uses. Species of Peperomia are often cultivated as house-plants, being favored for neat, fleshy-firm, shining, often patterned leaves and their ability to grow in filtered or indirect light (Cronquist, 1988). Piperaceae species can reproduce sexually and vegetatively. In the literature there is mention of vegetative propagation in Piper. Gartner (1989) estimated that more than $40 \%$ of the Piper plants had been propagated vegetatively in the lowland tropical forest of La Selva, Costa Rica. Greig and

\footnotetext{
* Author for correspondence: lasouza@uem.br
} 
Mauseth (1991) registered that the subterranean portions of adventitious roots of Piper auritum $\mathrm{L}$. grew horizontally and produced new shoots (root suckers). Piper species were propagated by several means, including stem sprouting, root sprouting, layering, and fragmentation (Greig, 1993). In forest remnants that occur in the northwest region of Paraná, Brazil, there are also Piperaceae species that spread vegetatively, by aerial or underground organs. This paper presents analysis and discussion on this propagation type in these species.

\section{MATERIAL AND METHODS}

The Piperaceae species that is Piper amalago L., $P$. arboreum Aublet, P. xylosteoides (Kunth) Steud., Peperomia parnassifolia Miq. and Ottonia martiana Miq. occur in the Horto Florestal de Maringá, Paraná, Brazil, forming a big shrubs. The collected material was selected identifying which plant regions presented vegetative propagation.

The anatomical analysis of the vegetative propagation organs was done using freshlycollected material or material fixed in FAA 50 (Johansen, 1940). This material was cut freehand or in a rotation microtome to make semipermanent and permanent slides, respectively for the microscopic studies, carried out according to the usual techniques. Sections were stained in astra blue, safranin and hematoxylin (Johansen, 1940; Dnyansagar, 1958). The following stains were used for specific color tests: phloroglucinol and sulfuric acid, Sudan IV and IKI for lignins, lipids and starch, respectively (Johansen, 1940; Souza et al., 2005).

The photographs were obtained with Sony digital camera (model DSC-P51). The photomicrographs were taken using image capture (Image Pro-Plus version 4.0 - Media Cybertecnics program, adapted to the Olympus microscope BX50).

Voucher specimes were deposited in the Herbarium of the Universidade Estadual de Maringá and registered as follows:

Piper amalago L. BRAZIL. Paraná, Maringá, Horto Florestal, 9885 (HUEM)

$P$. arboreum Aublet BRAZIL. Paraná, Maringá, Horto Florestal, 8821 (HUEM)

P. xylosteoides (Kunth) Steud. BRAZIL. Paraná, Maringá, Horto Florestal, 10582 (HUEM)

Peperomia parnassifolia Miq. BRAZIL. Paraná, Maringá, Horto Florestal, 11993 (HUEM)
Ottonia martiana Miq. - BRAZIL. Paraná, Maringá, Horto Florestal, 8974 (HUEM).

\section{RESULTS AND DISCUSSION}

The Piperaceae that occurred in Maringá forest remnant formed fruits and seeds and was seemingly viable and capable of germinating. Seeds, for instance of $P$. amalago (Souza and Rosa, unpublished data), P. crassinervium H. B. and K. and $P$. hispidum Sw. (Albiero, 2005) germinated and formed phanerocotylar seedlings. In spite of the possible sexual reproduction it was observed that Piperaceae species occurred as big shrubs and could spread vegetatively. The responsible organs for the propagation were aerial or underground.

In $P$. amalago, there was vegetative propagation by adventitious and plagiotropic roots that originated from the base of the plant. These roots presented secondary growth, with periderm; persistent collenchymatous and parenchymatous cortex with endodermis provided Casparian strips, and secondary xylem and phloem whose parenchymatous rays are rich in amylaceous content cellular (Rosa and Souza, 2004).

On the other hand, in P. xylosteoides (Figure 1) the aerial branched shoot, which were initially erect, bent and grew along the substrate surface (Figure 2) of the forest, showed adventitious roots (Figure 3) and could become independent of the original plant. Therefore, this branched shoot behaved as stolons and spread vegetatively the plant. In Ottonia martiana (Oliveira et al., 2005) and Piper arboreum were also formed stolons, starting from aerial branched shoot, although in the second species, the stolon could also be underground.

The organs involved in the vegetative propagation of P. xylosteoides, Ottonia martiana (Oliveira et al., 2005) and $P$. arboreum have stem structure. They presented uniseriate epidermis or periderm and collenchymatous and parenchymatous cortex (Figure 4). The inner collenchymatous cells of the cortex differentiated in the groups of fibers. In $P$. xylosteoides, the fibers formed a sclerenchymatous continuous ring in the cortex (Figure 4). The cortex was limited internally by endodermis with Casparian strips, except in P. xylosteoides. In the three species, the stele was constituted by two rings of collateral vascular bundles and parenchymatous pith (Figure 4). The peripheral ring of bundles was bounded internally and 
separated from the pith by a sinuous sclerenchymatous zone and had fascicular and interfascicular cambium (Figure 4). In the bundles of the inner ring, there was just fascicular cambium. In the pith bundles of the Ottonia martiana (Oliveira et al., 2005) and P. arboreum fibers could occur in the xylem outer margin and fiber primordia in the phloem face, not observed in P. xylosteoides.

In Peperomia parnassifolia there was also stolon. The vascular system of stolon consisted of scattered bundles embedded in the parenchymatous ground-tissue and each bundle was surrounded by endodermis with Casparian strips, characterizing a monostele.

An endodermis in the stem has also been recorded for other species of Piper (Bond, 1931), Peperomia (Takemori, 2002; Souza et al., 2004) and Ottonia (Souza et al., 2004). Bond (1931) tentatively concluded that the endodermis was a vestigial structure of no primary importance in the internal economy of the stem. Lersten (1997) reviewed the occurrence of the endodermis with a Casparian strip in the stem and leaf of vascular plants and considered that this strip in aerial organs had no known functional role.

Undoubtedly, the Piperaceae species of Maringá forest remnants, Brazil, adopted reproductive strategy by formation of new plants from budding of vegetative organs. In the analyzed species, only $P$. amalago presented root with budding ability. All the other species, besides the terrestrial species Peperomia parnassifolia, showed propagation by stem that behaved as stolon. However, root sprouting was registered in other species of Piper (Greig and Mauseth, 1991; Greig, 1993).
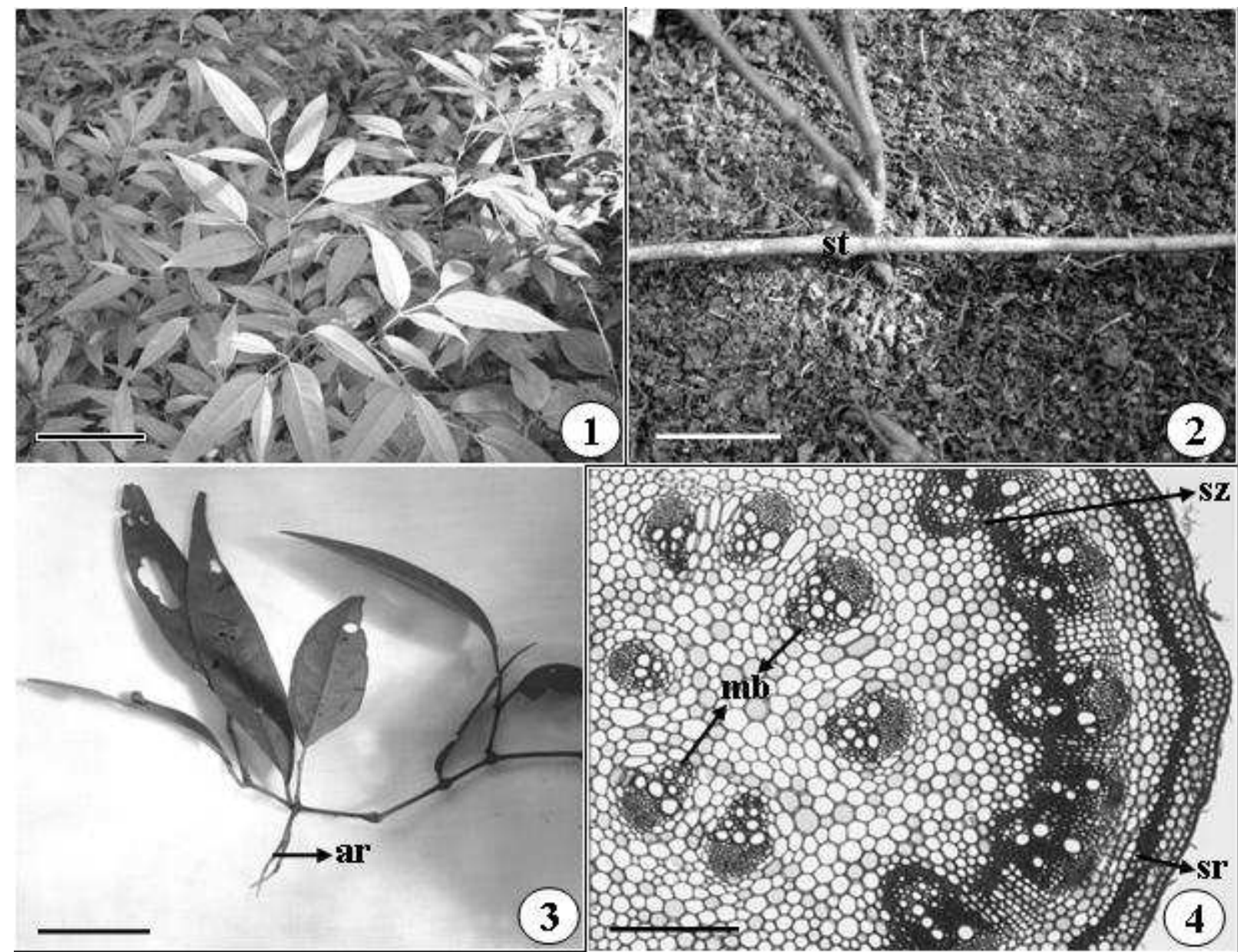

Figures 1 to 4 - Vegetative propagation in Piper xylosteoides. Fig. 1. General aspect of the plant. Fig. 2. Stolon with vegetative branch. Fig. 3. Vegetative branch with adventitious roots. Fig. 4. Detail of stolon in cross-section. (ar - adventitious roots; mb - medullar vascular bundles; sr - sclerenchymatous ring; st - stolon; sz - sclerenchymatous zone). Bars =

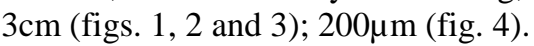


Clonal populations of arboreal species that are established by the process of bud formation on root systems have been registered (Appezzato-daGlória, 2003). According to Appezzato-da-Glória (2003) and Daubenmire (1974), the phenomenon of bud formation on roots was frequently observed in environments that were disturbed mainly by the action of fire. Rodrigues et al. (2004) registered species which sprouted from the root buds of forest fragment, affected by several fires.

In the case of the Maringá Piperaceae, the fire factor did not exist interfering in the propagation process. However, the environment of occurrence of these plants suffered significant anthropic action, when the original forest of this region was explored in no discerning and predatory condition. It should be emphasized that the vegetative propagation in Piperaceae should be studied in other forests. New and additional studies should be made if the structural variations were induced environmentally or fixed genetically.

\section{RESUMO}

Espécies de Piperaceae de remanescentes florestais de Maringá, Paraná, Brasil apresentam propagação vegetativa por meio de raiz ou caule (estolão). Este tipo de reprodução foi verificado em Piper amalago L., Piper arboreum Aublet, Piper xylosteoides (Kunth) Steud., Peperomia parnassifolia Miq. and Ottonia martiana Miq. Raiz e ramos caulinares destas espécies foram analisados anatomicamente segundo técnicas usuais. É necessário enfatizar que esse tipo de propagação em Piperaceae deve ser investigado em espécies que ocorrem em outras matas. Novos e adicionais estudos devem ser feitos para se saber se essas variações estruturais são induzidas pelo ambiente ou fixadas geneticamente.

\section{ACKNOWLEDGMENTS}

We thank CNPq (Conselho Nacional de Desenvolvimento Científico e Tecnológico, Brazil) and UEM (Universidade Estadual de Maringá, Brazil) for funding this study.

\section{REFERENCES}

Albiero, A. L. M. (2005), Morfoanatomia dos órgãos vegetativos e reprodutivos de Piper crassinervium $\mathrm{H}$. B. and K. e Piper hispidum Sw. (Piperaceae). Tese, Universidade Estadual Paulista, Rio Claro, Brasil.

Appezzato-da-Glória, B. (2003), Morfologia de sistemas subterrâneos - histórico e evolução do conhecimento no Brasil. Alexandre de Sene Pinto, Ribeirão Preto.

Bond, G. (1931), The stem endodermis in the genus Piper. Trans. Royal Soc. Edinburgh, 56, 695-724.

Cronquist, A. (1988), An Integrated System of Classification of Flowering Plants. Columbia University Press, New York.

Daubenmire, R. F. (1974), Plants and Environment - a textbook of plant autecology. John Wiley and Sons, New York.

Dnyansagar, V. R. (1958), Embryological studies in the Leguminosae VIII. Acacia auriculaeformis A. Cunn., Adenanthera pavonina Linn., Calliandra grandiflora Benth. Lloydia, 21, 1-25.

Gartner, B. L. (1989), Breakage and regrowth of Piper species in rain forest understory. Biotropica, 21, 303307.

Greig, N. (1993), Regeneration mode in neotropical Piper: habitat and species comparisons. Ecology, 74, 2125-2135.

Greig, N. and Mauseth, J. D. (1991), Structure and function of dimorphic prop roots in Piper auritum L. Bul. Torrey Bot. Club, 118, 176-183.

Johansen, D. A. (1940), Plant Microtechnique. Tata McGraw-Hill Book Company, Bombay.

Judd, W. S., Campbell, C. S., Kellogg, E. A. and Stevens, P. F. (2001) Plant Systematics: a Phylogenetic Approach. Sinauer Associates., Sunderland

Lersten, N. R. (1997), Occurrence of endodermis with a casparian strip in stem and leaf. Bot. Rev., 63, 265272.

Oliveira, J. H. G.; Souza, L. A. and Iwazaki, M. C. (2005), Estruturas de reprodução de Ottonia martiana Miq. (Piperaceae). Hoehnea, 32, 59-66.

Rodrigues, R. R.; Torres, R. B.; Mattes, L. A. F. and Penha, A. S. (2004), Tree species sprouting from root buds in a semideciduous forest affected by fires. Braz. Arch. Biol. Techn., 47, 127-133.

Rosa, S. M. and Souza, L. A. (2004), Estruturas de reprodução de Piper amalago var. medium Linnaeus (Piperaceae). Acta Cienc. Venez., 55, 27-34.

Souza, L. A.; Moscheta, I. S. and Oliveira, J. H. G. (2004), Comparative morphology and anatomy of the leaf and stem of Peperomia dahlstedtii C.DC., Ottonia martiana Miq. and Piper diospyrifolium Kunth (Piperaceae). Gayana Bot., 61, 6-17. 
Souza, L. A.; Rosa, S. M.; Moscheta, I. S.; Mourão, K. S. M.; Rodella, R. A.; Rocha, D. C. and Lolis, M. I. G. A. (2005), Morfologia e Anatomia Vegetal Técnicas e Práticas. Editora Universidade Estadual de Ponta Grossa, Ponta Grossa.

Takemori, N. K. (2002), Anatomia comparada de Peperomia catharinae Miquel, P. emarginella (Sw.) C.DC., P. quadrifolia (L.) Kunth e P. rotundifolia (L.) Kunth (Piperaceae). Dissertação, Universidade Federal do Paraná, Curitiba, Brasil.

Yuncker, T. G. (1958), The Piperaceae - a family profile. Brittonia, 10, 1-7.

Yuncker, T. G. (1972), The Piperaceae of Brazil - I. Piper - group I, II, III, IV. Hoehnea, 2, 19-366.
Yuncker, T. G. (1973), The Piperaceae of Brazil - II. Piper - group V; Ottonia; Pothomorphe; Sarcorhachis. Hoehnea, 3, 29-284.

Yuncker, T. G. (1974), The Piperaceae of Brazil III: Peperomia - taxa of uncertain status. Hoehnea, 4, 71413.

Yuncker, T. G. (1975), The Piperaceae of Brazil IV: index. Hoehnea, 5, 123-145.

Received: November 24, 2006; Revised: April 30, 2007; Accepted: January 22, 2009. 